\title{
"I Overcome Fate, Fate Harkens to Me"
}

\author{
By JAN BERGMAN
}

SOME OBSERVATIONS ON ISIS AS A GODDESS OF FATE

"I overcome Fate (to heimarmenon); Fate harkens to me". In order to understand the tension in this proclamation of Isis, which forms the conclusion of the Isis aretalogy from Cyme, ${ }^{1}$ we must make a closer acquaintance with the two dramatis personae. With what right could Isis make a claim like this? How was to heimarmenon understood and experienced in the Hellenistic environment to which the Cyme hymn belongs?

Let us consider the Egyptian goddess and her relation to Fate. The topic is vast, the time is brief. Therefore it is only possible to point out a few 'fatalistic traits' in Isis' character. But first we have to ask another question: How did the Egyptians understand Fate in general? What concepts did they use in order to define Fate and its effects? What was the relation between the $\operatorname{god}(\mathrm{s})$ and Fate?

The answer to these questions can be made relatively brief by referring the reader to the recent work by S. Morenz and D. Müller, Untersuchungen zur Rolle des Schicksals in der ägyptischen Religion, ${ }^{2}$ which deals precisely with these problems. A good introduction is given by $\mathrm{H}$. Bonnet in his Reallexikon der ägyptischen Religionsgeschichte under the headings 'Schicksal' and 'Schai'. G. Thausing's Der ägyptische Schicksalsbegriff, ${ }^{3}$ which is treated

1 For the Isis aretalogies, see above all P. Roussel, "Un nouvel hymne grec à Isis", REG 42, I929, pp. 137 ff., W. Peek, Der Isishymnus von Andros und verwandte Texte, Berlin I930, R. Harder, "Karpokrates von Chalkis und die memphitische Isispropaganda", $A P A W$, I4, I943, Berlin I944, A.-J. Festugière, "A propos des arétalogies d'Isis", HThR 42, I 949, pp. 209 ff., A. D. Nock, review of Harder, Gnomon 21, I949, pp. 22 I ff., D. Müller, "Ägypten und die griechischen Isis-Aretalogien", $A S A W$ 53: $\mathrm{I}$, Berlin I96r.

$2 A S A W$ 52: 1, Berlin 1960.

${ }^{3} M D A I K$ 8, I939, pp. $46 \mathrm{ff}$. 
somewhat grudgingly by Morenz, should also be mentioned here, and C. J. Bleeker has dealt with this topic too. ${ }^{1}$

The first time we meet with a fairly well defined concept of fate is in a text from the I8th dynasty. In the biography of Ahmose from Elkab (Urk. IV,5) it is said of a rebel, "His fate and his death draw near". The word that is here translated as 'fate', $s^{\prime}$ '.w, is a verbal noun from the root s' $y$, to ordain. From a formal point of view it can be taken as a nomen agentis 'the ordainer', as a nomen actionis or abstractum, 'the ordainment', or as a passive perfect participle 'that which is ordained'. Bonnet is inclined to understand the word in the active sense, ${ }^{2}$ while Morenz, against the background of the comprehensive material that he presents in his investigation, emphasizes the passive meaning of the concept. ${ }^{3}$ The oldest example of the verb s's $y$ mentioned by Morenz is from the Teaching of Ptahhotep and consequently dates back to the Old Kingdom. ${ }^{4}$ In the well-known biography of Sinuhe the word occurs twice, characteristically enough in connection with $n t r$, '(the) god'. In the case of Sinuhe it is his unhappy flight from Egypt that is "the fate decreed by the gods". In the passage from Ahmose just mentioned the context is still more typical: it is death that is decreed. Morenz points out that the statements about $\breve{s}$ '.w are very often concerned with the regulation of man's length of life. ${ }^{6}$ The combination $s^{\prime} . y t$ ' $n h$, 'decree(ing) of life' is important to note. It is also illuminating that $\xi^{\prime \prime} . w$ is sometimes followed by the determinative for 'death' and at other occasions by the sign for 'time'.

As already alluded to in the examples from Sinuhe, $s^{\prime} . w$ is often expressly connected with the god or gods. In view of the Egyptian idea of god it is natural that the primeval god-the creator-the sky-god should be the one who decrees. As Morenz remarks, the verb 's'y even tends to take on the

1 C. J. Bleeker, "Die Idee des Schicksals in der altägyptischen Religion", The Sacred Bridge (Suppl. to Numen VII), Leiden I963, pp. I $12 \mathrm{ff}$.

2 RÄRG p. 6I I.

${ }^{3}$ Op. cit. pp. $23 \mathrm{f}$.

4 Ib. p. 15.

5 Notice the vague expression $n t r . w n b$ (B I $_{5} 6$ ), approximately "any god", "a god whoever it may be". Notice also that the terminology for the interference of fate is not quite fixed; in B 43 the expression shr ntrr, "God's plan" is used instead. (cf Morenz, op. cit. p. I6).

${ }^{6}$ Op cit. pp. $18 \mathrm{f}$. 
meaning of 'to create'. ${ }^{1}$ Horapollon's observation that according to the Egyptians "nothing exists without God" $\left(\mathrm{I}, \mathrm{I}_{3}\right)$ illustrates well the sovereign position of the god in Egyptian thinking and belief. Just as the god (or goddess) appears as the 'lord of life', the 'lord of time (or times)' etc., he also bears the title $n b(. t)$ 's. $w$ 'the lord of fate', which Bonnet records with reference to Re, Amon, Ptah, Khnum, Thot, and Hathor as well as to Pharaoh. ${ }^{2}$ A passage in a Leiden hymn to Amon $(I I I, 7)$ deserves mentioning here: "He lengthens the time of life, he shortens it, he grants an addition to fate to the one he loves." This $h$ '.w $h r s^{\prime} \cdot y t$, 'addition to fate'-which also appears in WenAmon's (2Ist Dyn.) prayer to Amon for a $5^{\circ}$ years' 'addition to his fate' 3 leads our thoughts to Isis' proclamation to the transformed and converted Lucius (Apuleius, Metam. XI,6,6): scies ultra statuta fato tuo spatia vitam quoque tibi prorogare mihi tantum licere, " "you shall know that I and I alone have the power to prolong your life beyond the bounds appointed as your fate". Thus Isis appears as the inheritor of Amon-the myth of Isis taking possession of (Amon-)Re's secret name reflects in its popular naive manner the development within the Egyptian hierarchy of gods. The claims of the two deities seem to be identical. Nevertheless there is no doubt-as we shall see - that the compact fatalism of Hellenism extends the sphere of influence of fate-ruling Isis as seen in Apuleius-and the Isis of the Cyme hymn.

It is no cause for surprise that Isis appears in Egyptian texts as one of the gods who control fate. Through her incorporation into the Heliopolitan ennead, her active part in the Osiris drama, and her important position in the royal ideology, Isis, who was probably originally a local goddess in the Lower Egyptian Iseion, aquired a more and more dominating role in the Egyptian pantheon.

Thus Isis appears as $n b(. t)$ 's. $y t$ śhpr rnn(.t), "Mistress of fate, who creates destiny", and as $n b(. t)$ " $n h$ h hnw.t š'.yt $r n n(. t)$ "Mistress of life, ruler of fate and destiny." ${ }_{5}$ In a hymn from Assuan Isis is referred to as $\tilde{s}^{\prime}, y t$ rnn $(. t)$

$1 \mathrm{Ib} . \mathrm{p} .17$.

2 Op. cit. p. 67I.

4 Morenz, op. cit. p. ז2.

4 Mihi tantum here seems to correspond to the $\varepsilon^{\prime} \gamma \omega$ of the Cyme hymn with the emphasis this word receives through the anaphora.

5 For the provenience of these two examples, see Müller, op. cit. p. 84, n. 8. As regards $r n n . t$ which is so frequently used together with $\breve{s}^{\prime} w$ I agree with Morenz' 
wd.t.n.s, "the One under whose command fate and destiny is". And in the temple of Philae (Pylon $76,4^{-6}$ ) she is said to be "Mistress of the jubilees, with a long reign, who 'lengthens the years' for the one who obeys her and makes his office last for ever".

The last example, which is in addition reminiscent of the quotation from Apuleius, shows the important role time plays in the statements concerning fate. Fate is not only intimately connected with time, it is often even identified with it. In other words, no distinction is made between time and its contents. Time is inevitably bound up with what occurs in it. He who has time in his hand also has fate at his command. ${ }^{1}$

Against this general background I should like to emphasize one trait in the Isis figure, which in my opinion has determined Isis' connection with fate. I mean the identification of Isis with the Sothis star (Sirius). This combination is well instanced as early as the Pyramid texts, where, for example, a passage concerning the birth of Horus (Pyr. 632) bears witness to the identification of Isis with Sothis (Śpd.t) with a typical pun $s^{\prime} p d-\dot{s} p d . t$. Neugebauer and Parker ${ }^{2}$ even launch the hypothesis that the original term for Sothis was $S p d$ and that the ordinary form $S p d . t$ should be taken as a nisbeh adjective referring to Isis as "the one who is connected with Sothis". They also emphasize the fact that Sothis-Sirius is the most original example of the use of stars for measuring time. ${ }^{3}$ For the Egyptians thought that the Sothis star through its heliacal rising not only announced but itself brought about the rise of the Nile and therewith the beginning of the natural year. Thus the Sothis star was intimately bound up with the destiny of Egypt in all its aspects.

Some temple texts refer to this. "Isis-Sothis who discharges the flood of the Nile in due season" is mentioned in Edfu; in Dendera she is "Sothis in the sky who at New Year brings the flood of the Nile"; and in Assuan Isis

interpretation, op. cit. pp. $20 \mathrm{ff}$., according to which it would imply something like 'the development of events', and I suggest 'destiny' as an approximate translation. In later texts the pair $\breve{s}$ '.w-rnn.t seems to correspond to Agathos Daimōn-Agathe Tyche , behind which often Osiris (Sarapis) - Isis may be suspected.

1 For the motif of time-fate, see e.g. H. Ringgren, "Dieu, le temps et le destin dans les épopées persanes", Yournal de Psychologie 53, 1956 pp. $407 \mathrm{ff}$.

2 Egyptian Astronomical Texts I: “The Early Decans", London 1960, p. 25.

3 Op. cit. pp. $106 \mathrm{f}$. 
is addressed: "Isis, you who pour out the Nile in order to flood the two lands, in this your name 'Sothis'." 1 The combination Isis Sōthis occurs also in Greek, e.g. PGM II,33, and perhaps also in the well known Isis litany. ${ }^{2}$

Coins and amulets from Hellenistic and Roman times as well as the tympanum of the Isis temple on the field of Mars in Rome, which depicts a dog with a star, bear witness to the importance of the combination of Isis with Sothis, the dog-star, and shows how this idea was alive in Hellenistic times. Thus it also says in the Cyme hymn:" It is I who rise in the dog-star", and it is to be noted that $\dot{\varepsilon} \pi \iota \tau \hat{\varepsilon} \lambda \lambda \varepsilon \sigma \vartheta \alpha_{l}-\dot{\varepsilon} \pi \iota \tau 0 \lambda \eta \dot{n}$ is the terminus technicus for the heliacal rising of a star.

In this manner Isis-Sothis ${ }^{3}$ came to play a key part in the determination of the year's destiny. A quotation from Horapollon, I,3, shows this: "When the Egyptians want to render 'year' they draw Isis, i.e. a woman (in this way they also render 'goddess'). For according to them Isis is a star called in Egyptian Sothis, in Greek Astrokyon, which is thought to rule (or, to be queen, $\left.\beta \alpha \sigma u \lambda \varepsilon^{\prime} \varepsilon \iota v\right)$ over the other stars, rising sometimes big, sometimes small, sometimes with greater, sometimes with less brightness. Therefore it is also according to the rising of this star that we make interpretations concerning everything that is to happen during the year. It is therefore not without reason that they call the year Isis." Another passage from the same excellent collector of facts (Horap. I, 13 ) offers a combination of god, star, and fate which may be of interest: "When they (the Egyptians) render a

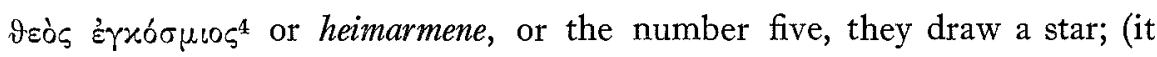
denotes) a god because God's providence decrees the victory through which the movement of the stars and of all the cosmos is completed; and further, heimarmene because this too is composed according to the 'economy' of the

1 These texts are reproduced by Müller, op. cit. p. 34, n. I I and I 2 and p. 35, n. I, where also further evidence is collected.

2 P. Oxy. I380, 143, which by the editors, Grenfell and Hunt, is interpreted as 'Iő $\Sigma \tilde{\omega} \vartheta \iota$, while Manteuffel, De opusculis graecis Aegypti e papyris ostracis lapidibusque collectis, Warszawa 1930 , p. 80 reads 'I

3 For further examples of this combination, see Belegstellen to $W B$ IV, I I I, i8.

${ }_{4}$ This is not the place for a detailed study of this interesting concept of god. See, provisionally, Sbordone's commentary (Hori Apollinis Hieroglyphica ..., Napoli 1940) pp. 35 f., which, however, does not analyze the Hellenistic concept but only hunts for the Egyptian counterpart. 
stars ( $\alpha \sigma \tau p \operatorname{ci} \dot{\eta}$ oixovouí $\alpha)$..." 1 These two quotations show that Isis-Sothis as the queen of heaven ${ }^{2}$ rules the other stars and that heimarmene is directly bound up with the constellations of the stars, a fact that has resulted from the role of the Sothis star as the announcer and bringer of the new year. ${ }^{3}$

From the relation between Isis and the year there is some interesting material. Especially noteworthy is a text rendered in Brugsch Thes. I07, where (Hathor-) Isis is called Rnp.t, "the Year", precisely in Memphis. In the Oxyrhynchus litany (1. 46) we find the name Eseremphis which van Groningen interprets as 'Isis-the Year', ${ }^{4}$ while 11 . I 54 f. connect her with "the 365 combined days". In my opinion these and similar statements can be put in a meaningful context, if we visualize some kind of ceremony to

1 This passage, typical of Horapollon in its style of loose associations, is worth some comments. It is well known that Isis often appears as Pronoia theou or providentia dei. (For the former, see e.g. R. Reitzenstein, Zwei religionsgeschichtliche Fragen, Strassburg $190 \mathrm{I}$, index s.v., and below p. 44 n. I; Apuleius' use of providentia will be dealt with below.) The occurrence of the word nike in this context should be especially noticed. The word has caused the translators some difficulty: Leemans emends it to din $\bar{e}$, and Trebatius in his Latin translation omits the word. I should like to suggest that the argument here is parallel to the statement about Isis' victory over to heimarmenon in the Cyme hymn: pronoia theou (possibly = Isis) ordains nike, which governs the movements of the celestial bodies, with which heimarmene is intimately connected. It is also worthy of notice that prostassein and akouein are correlated technical terms in astronomy-astrology (e.g. Ptolemaios, Tetrabiblos, I, 14).

2 Of Isis (-Sothis) it is said in a text: "She gives her son (Pharaoh) the kingdom of Sothis in the sky" (Brugsch, Thesaurus p. Iro). It is also at an invocation of Regina coeli (Apul. Metam. XI,2) that Isis appears to Lucius.

3 Sbordone, op. cit. p. 36 , has found no hieroglyphic evidence for "fate" written with a star. Instead he refers to general speculations, e.g. in Chairemon (quoted by Eusebius, Praep. ev, III, 4,2). There, immediately after the passage quoted by Sbordone, in which the unbreakable fetters (alytoi desmoi) of fate are mentioned, the gods -and it is only Isis and Osiris that have been expressly mentioned in what precedesare described as "the only ones who can free (man) from Fate" (lytêras tês Heimarmenes monous). Cf. with this the Cyme hymn v. 48:" I set free those who are in fetters" (egõ tous en desmois lyō). Iamblichus, De mysteriis 8,7 deals at length with the topic lyein tên Heimarmenēn (see extracts in Müller, op. cit. p. 79). O. Weinreich has devoted a special study to the motif of the gods as those who free from fetters etc., Gebet und Wunder, Stuttgart 1929 , Zweite Abh: "Türöffnung ..." pp. $34 \mathrm{ff}$.

4 B. A. van Groningen, De papyro Oxyrhynchita I380, Diss. Groningen I 92 I, p. I7. One might ask if this name or a corresponding expression also occurred in the fragmentary 1. 4, where Memphis is referred to by the archaizing expression 'Ptah's house", as is also the case in the text quoted by Brugsch. 
determine the 'destiny' of the year to come performed at Memphis' during the intercalated days with Isis-Sothis as the leading figure (according to ancient tradition the fourth intercalated day was the day of Isis par excellence). This allusion may suffice for the moment; for a general orientation, recourse may be had to Prof. Säve-Söderbergh's paper “Några egyptiska nyårsföreställningar". ${ }^{2}$

We have now, against the background of the Egyptian view of god and fate, briefly introduced the Isis who proclaims "I overcome Fate". Let us now direct our attention to heimarmene. But first we should notice an important fact that seems to have been entirely overlooked hitherto. The Cyme hymn speaks of to heimarmenon in the neuter singular form instead of in the otherwise prevailing feminine form he heimarmene $\bar{e}^{3}$ It might seem remarkable that this latter form does not occur in our hymn, especially

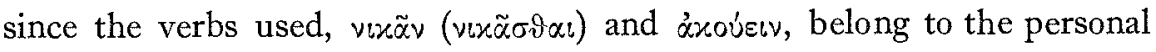

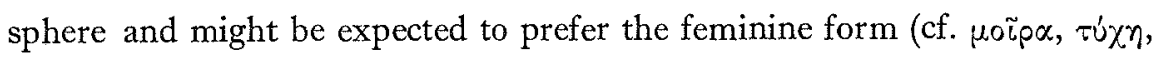

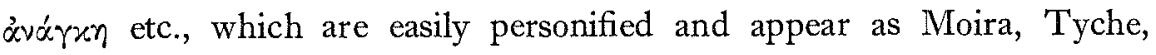
Ananke). Could it be that precisely the form to heimarmenon represents an Egyptian concept like $\check{s}^{\prime} . w$ ? If this is so it would contradict the hypothesis that the two concluding lines of the Cyme aretalogy are a later addition (thus Roussel, Festugière, and, with some hesitation, Nock). Against the hypothesis I would also adduce the fact that earlier statements in the hymn may be said to anticipate and prefigure this final climax, which would necessitate the assumption of rather radical changes in the original tradition. I have in

I Cf. also Thausing, op. cit. p. 50 n. I, concerning Memphis and especially the temple of Ptah as $m h^{\prime} . t t$ '.wy, "the balance of the two lands", and Brugsch, Thesaurus p. I02, which refers to the New Year's Day as "the great festival at which the whole world is brought into balance, when the birth of Isis talses place."

2 Religion och Bibel 9, I 950, pp. I ff.

3 Impersonal verbal expressions derived from this root are known to be common, e.g. in Homer ( $\left.\varepsilon^{\prime} \mu \alpha \rho \tau \alpha, \varepsilon^{\prime \prime} \mu \alpha \rho \tau \sigma\right)$, and the plural form of the participle, $(\tau \dot{\alpha})$

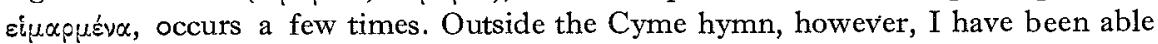

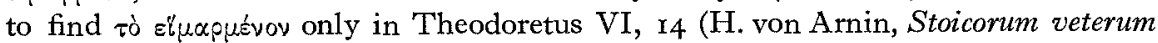
fragmenta II, Leipzig $1903,265,29$ f.: "And Chrysippus the Stoic said that that

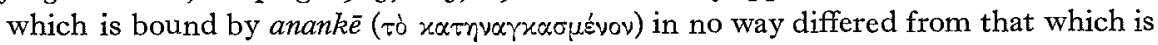

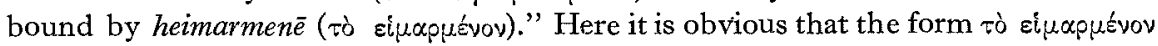
finds its explanation in the other part of the comparison, which could only be expressed in this form (not in the feminine form). 
view lines 46-47: "Whatever I please, this too shall come to an end. For me

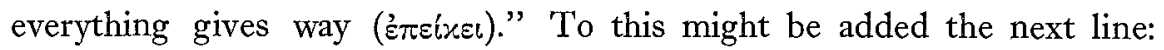
"I set free those in bonds". 1

On the other hand it is incontestable that to heimarmenon in the Hellenistic environment immediately suggests he heimarmene. The predominant role of the latter in this epoch is borne out by many contemporary witnesses, whose testimonies have been collected by modern scholars. Here we may content ourselves with a reference to W. Gundel, who in various contexts has dealt with the concept of heimarmene $\bar{e}$ and its development. ${ }^{2}$ An excellent introduction is provided by $\mathrm{D}$. Amand in the introductory chapter of his work Fatalisme et liberté dans l'antiquité grecque. ${ }^{3}$ Heimarmene, which had been of some importance in Greek philosophy ever since Heraclitus, gained its sovereign power over Hellenistic man especially through two factors: Stoicism and astrology. From different points of departure and on different levels the 'Chaldæans' and the Stoics built up the hegemony of heimarmenē. It is with this in mind that Cumont could say: "En certains cas le stoicisme fut une philosophie sémitique." 4 Posidonius of Apamea, who is probably the most typical example of the merger of these two lines of thought in one person, is characterized as magnus astrologus idemque philosophus, fatalium siderum assertor. ${ }^{5}$ According to its opponent Plutarch, Stoicism professes "heimar$m e n \bar{e}$ which is invincible, and not to be overpowered and victorius over everything." 6

Hermetic literature often deals with heimarmenē, though not unequivocally.

1 The verb हं $\pi \varepsilon i x \omega$ is not instanced earlier. Is there perhaps an Egyptian concept at the basis of this new-coined (?) word? Müller, op. cit. pp. 7 I f., refers to the Egyptian word $h m y$, "to retire, retreat", which is often used in connection with gods and kings. The simple word $\varepsilon$ ' $\varkappa \omega$ is perhaps found in an Epidaurian hymn: ool $\delta \dot{\varepsilon}$

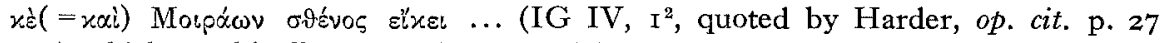
n. 4), which would offer an excellent parallel to our passage. For v. 48 , see above n. 24.

a The article "Heimarmene" (RE I4, I912, 2622 ff.) and Beiträge zur Entwicklungsgeschichte der Begriffe Ananke und Heimarmene, Giessen I9I4.

3 Diss. Louvain I945.

4 F. Cumont, "Fatalisme astral et religions antiques', RHLR 3, 1912, p. 519, quoted by Amand, op. cit. p. I2.

5 Augustine, De civ. Dei V,5 (cf. also V,2).

6 De Stoic. repugn. 46,1055 d. Cf. a little later $(47,1056$ b), where heimarmene is said to be "the causal law which cannot be overcome, prevented or averted" ( $\alpha i \tau i \alpha$

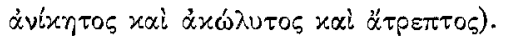


In Stobaeus $(1,82,5)$ we read: "The stars serve heimarmene. For no one can escape heimarmene or protect himself against its harshness. For the tools of heimarmene $\bar{e}$ are the stars." 1

In an astrological work (Catal. cod. astrol. VI,4I,II) we read: No one is free, we are all slaves of heimarmene"'. Cumont's work L'Egypte des astro$\operatorname{logues}^{2}$ paints in detail a pathetic picture of the cruel conditions of this slavery. Heimarmene $\bar{e}$ was felt as an inescapable ananke dependent on the stars which even from man's birth had fixed his destiny.

We have to visualize this basic attitude of Hellenistic man towards his situation in order to understand what a 'gospel' Isis proclaims: "I overcome Fate. Fate harkens to me." Earlier she has proclaimed herself the one who rises in the dog-star. It is worthy of notice that $\dot{\varepsilon} \pi \iota \tau \dot{\varepsilon} \lambda \lambda \omega$ which was translated by 'rise' is not in the passive form which is the usual one in this sense, but in the active, where the translation 'to enjoin, command' is the normal one. Is this done on purpose to emphasize the commanding authority of Isis-Sothis? An Isis hymn form Cyrene ${ }^{3}$ says expressly: "And the stars do

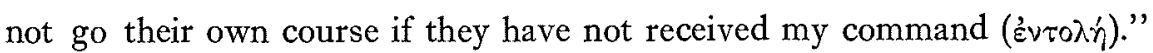
And the Isis creatrix of the Cyme hymn proclaims (v. I3 f.): "I showed the paths of the stars. I ordered the course of the sun and the moon." 4

A quotation from Valentinian gnosticism ${ }^{5}$ shows how concretely such statements were understood. After a description of the stars being in conflict with each other because of heimarmenē come glad tidings: "Therefore a new alien star rose to destroy the old constellation ... to transfer those who believe in Christ from heimarmene to His providence." A passage in the Isis litany (P. Oxy. 1380, I5I f.) refers to those who have faith in Isis: "Thou art seen by those who invoke thee faithfully". It has already been pointed out that

1 Notice however that in this case heimarmene in its turn serves pronoia and anankē. For heimarmenë in the Hermetic writings, see J. Kroll, Die Lehren des Hermes Trismegistos, Münster I9I4, pp. $212 \mathrm{ff}$., and W. Bousset's important review of this work in Göttingische Gelehrte Anzeigen r9 14, pp. $697 \mathrm{ff}$.

2 Bruxelles 1937.

${ }^{3}$ Text in Peek, op. cit. p. 129, as supplied by Oliverio.

4 The Cyme hymn itself offers several instances to prove that there is no opposition between the aorist of creation and the present of providence. From the Egyptian point of view this is a matter of course.

${ }_{5}$ Clemens of Alexandria, Excerpta ex Theodoto 74. 
Isis often appears as Pronoia-Providentia. ${ }^{1}$ In the Isis book of Apuleius this is the leitmotif. Isis says (XI, 5, 4): Iam tibi providentia mea inlucescit dies salutaris, "The day of salvation already begins to dawn for you through my providence." Later $(\mathrm{I} 0,4)$ there is a reference to deae summatis auxiliaris providentia, "the helping providence of the highest goddess." And this is how Lucius himself views his imminent transformation: ... deae maximae providentia adluctantem mihi saevissime Fortunam superarem, "Through the providence of the greatest goddess I overcame Fortune, who attacked me so fiercely." Here providentia Isidis stands contra Fortune in the same way as Isis stands contra to heimarmenon in the Cyme hymn. The Isis priest's solemn address to Lucius (XI, $\mathrm{I}_{5}$ ) presents this in still sharper relief. Referring to the tempests of fate that he has been exposed to he says: "However it was, the blindness of Fortune (Fortunae caecitas), while torturing you with the worst of perils, has with a malice which proved shortsighted (improvida) brought you to this pious happiness. Let her go now and rage with her worst frenzy and seek some other object for her cruelty; for hostile chance has no power against those whose lives have been claimed for service (servitium) by the majesty of our goddess. What profit did spiteful Fortune (nefaria Fortuna) derive from robbers or wild beasts or slavery or the hardest of journeys, bringing you back to where you started, or the daily fear of death? Now you have been taken under the protection of Fortune, yes, and a Fortune that sees (Fortunae videntis), that by the splendour of her radiance gives light even to the other gods."2

Here we notice the sharp contrast between Fortuna caeca ${ }^{3}-n e f a r i a$ and Fortuna videns-salutaris. But at the same time we note that the service, or slavery of both is denoted by the same word, servitium. This is emphasized by the concluding words of the priest's speech where, after referring to

1 In P. Oxy. 1380,43 Isis is pronoia. Plutarch, De Iside 3 and 67 also connects pronoia with Isis. The Stoics often struggled with the problem of uniting pronoia and heimarmenë. See, e.g., von Arnim, op. cit. p. 264, 19, where heimarmene is defined as

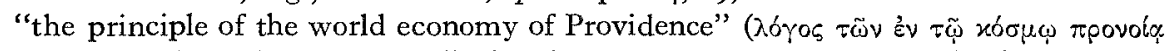
$\delta$ couxoupévwv), and p. 280, I5: "What happens according to Fate, also happens ac-

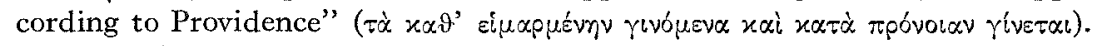

${ }_{2}$ Transl. according to A. D. Nock, Conversion, Oxford I933, pp. I40 f.

3 Blind Fate is a common topos, e.g. Stob. Ecl. I, VII, frg. 3 (Menander?): "Fate

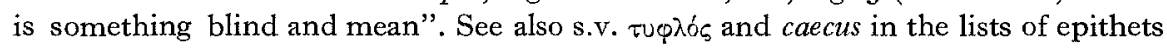
in the supplement of Roscher's Ausführliches Lexikon ... 
ministerii iugum voluntarium, he says: Nam cum coeperis deae servire, tunc magis senties fructum tuae libertatis, "For when you have begun to serve the goddess, then you will the more perceive the fruit of the liberty which is yours." The resigned statement "All are the slaves of Fate" has already been quoted.

Vettius Valens, the astrological popularizer, uses another metaphor: men are the soldiers ( $\sigma \tau \rho \alpha \tau \iota \tilde{\omega} \tau \alpha \iota)$ of heimarmene $(\mathrm{V}, 7)$ and they are asked to "fight nobly on the side of the times (i.e., of fate)" (VII, 2), thus adopting the ideal of Seneca and Marcus Aurelius-the Stoics are well known for their amor fati. It is characteristic that this military terminology is found also in Apuleius in the section just quoted. Here we find a reference to Lucius' militia deae: he joins the cohors religiosa of the goddess and swears his sacramentum (oath to the colours) when entering this sancta militia. ${ }^{1}$

I overcome Fate - this was the fanfare of the Cyme hymn. As we have seen, proclamations of victory are not lacking in the Isis book of Apuleius either. Fortunam superarem (XI, I2, I) has already been quoted. Further down he says: Et ecce pristinis aerumnis absolutus Isidis magnae providentia gaudens Lucius de sua Fortuna triumphat, "Lo, Lucius freed from his old woes by the providence of great Isis triumphs joyously over his own fortune" (XI, I5,4). These words are placed in the mouth of the irreligious, who have to see and admit their mistake. This suggests that the poet has had in mind some kind of "Toเs vix $\tilde{\alpha}$ acclamation of which there are several instances. ${ }^{2}$

The tremendous significance of Isis' proclamation that she overcomes Fate is easily realized if it is remembered how often it is Fate that is described as victorious, unconquered, or invincible. Thus an inscription ${ }^{3}$ speaks of

1 For this terminology, see F. Cumont, Les religions orientales ... 4th ed., Paris 1929, p. 207 n. 7. It is interesting to compare with this the magician's declaration in Pap. Paris ro, 5 ff., quoted by van Groningen, op. cit. pp. 77 f.: "I am the one who has struggled with the gods together with you, I, your soldier, have been defeated by the gods".

2 O. Weinreich, Neue Urkunden zur Sarapisreligion, Tübingen 1919, Beilage IV,

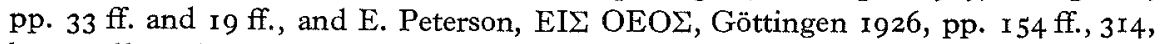
have collected such formulae. They are above all connected with Sarapis and Isis, but were later adopted by the Christians, Weinreich, op cit. Beilage V, pp. $35 \mathrm{ff}$.

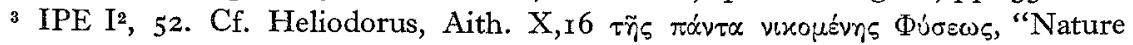
that overcomes everything", where Physis is more or less identical with Heimarmene. 


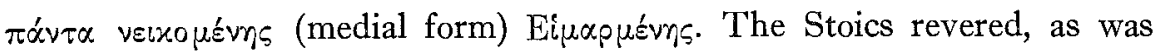
mentioned, Invincible Fate. There are many similar statements concerning Tyche, e.g. a fragment from Chairemon (Stob. Ecl. I,VI, I5): “Tyche overcomes and changes everything, and nobody is victorious without Tyche's will". Against this background victorious Isis stands out with increased power. In Delos there is an inscription dedicated to Isis Nike, ${ }^{1}$ and together

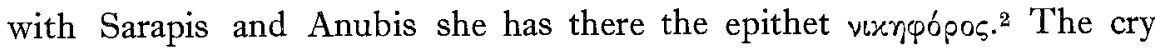
vผxं́ $\sigma \circ \varepsilon v$, "we shall win" plays an important part in a lawsuit concerning the site of a temple for the Egyptian gods of the island. ${ }^{3}$ In a Leiden papyrus we read about Sarapis "who, with Isis, gives you victory (and) power over all the world".4 In Latin inscriptions we often meet with Isis victrix (CIL VI, 352; IX, 3144, 5179; XI,695) as well as Isis invicta (CIL VI, 353); Isis triumphalis also occurs. ${ }^{5}$ It is even possible that the opening line of Isis' self-introduction in the Cyme hymn should be related to statements about Fate. In an anonymous fragment (frg. adesp. 506) it says: "Fate ( $\left.\tau \dot{\gamma} \chi \eta_{1}\right)$ is the mistress (zúpavvos) of all the gods". Isis says: "I am Isis, the mistress

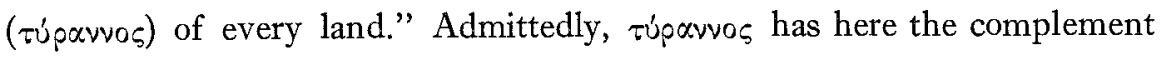
'every land' (i.e. the whole earth), but the Cyrene aretalogy begins with a

For the combination of Isis and Physis, which sound much more similar through itacism, reference should be had to Athenagoras Athenaios, Suppl. 22,5 f.: "Isis, who they say is the nature (physis) of the world, from whom all beings have come into existence and through whom all beings exist". Hippolytus, Refut. V, 22 f., refers to Isis as Physis heptastolos, 'seven-robed Nature', which is given a cosmic interpretation. One may also compare with this the Isis epithet "prototype of everything" in late Egyptian texts and rerum naturae parens in Apuleius, Metam. XI,5. It is against this background that the alchemistic physis formula should be viewed (below p. $4.9 \mathrm{n}$. I). 1 A. Rusch, De Sarapide et Iside in Graecia cultis, Diss. Berlin 1906, p. 44; P. Roussel, "Les cultes égyptiens à Délos", Annales de l'Est, $29^{\mathrm{B}}$ et $30^{\circ}$ années, I $9 \mathrm{I} 5$ et I9I6, Nancy, No. I2r, p. I49.

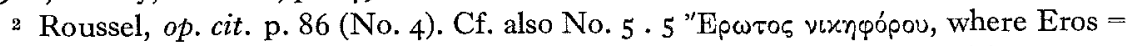
Harpokrates. It should be noticed that the Ptolemæans also wore that epithet.

3 Roussel, op. cit. p. 72 (No. I). Cf. Weinreich, op. cit. p. 20. Does this nikēsomen reflect a cultic cry?

$4 \mathrm{UPZ} \mathrm{I}, 20,63 \mathrm{ff}$. (p. 200), cf. p. $3 \mathrm{I}$. It is a matter of course that also actual political conditions have played their part here. For the historical situation, see W. Otto, "Zur Geschichte der Zeit des 6. Ptolemäers", $A B A W$ NF II, I934, p. 95.

5 The evidence has been collected by Drexler, Wochenschrift filr klassische Philologie I886, col. 1432-34. Cf. also the same writer in Roscher, Ausführliches Lexikon II, I, 52 I. 


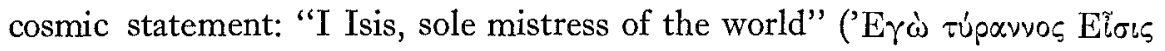

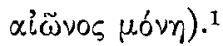

Thus we see how Isis overcomes Fate-but at the same time adopts the role of Fate. Instead of invincible Fate we find Isis invicta. In Lucius' case, servitium under atrocious Fate is exchanged for servitium under the providence of Isis. The soldier of Fate has entered the cohors religiosa of Isis. To us this might seem contradictory. Still it is characteristic of the world of fatalism, or rather, of all religion. The power of Fate, the omnipotent, which gives and takes arbitrarily, is always experienced in an indirect way through the fate of the individual. The individual lot is easily personified which leads to the many different shapes of Tyche-Fortuna. We have no right to analyze logically who decreed what destiny. According to the laws of religon we are in this case always taken back to Isis the Highest, the goddess of Fate, who overcomes Fate, the Egyptian Isis who is $n b . t s^{\prime} . w$ but at the same time also Fate itself. We have to remember that even in Egypt the gods and Pharaoh seem not only to have appeared as the masters of Fate but also identified themselves with Fate, a feature that has been somewhat neglected in Morenz' book. ${ }^{2}$ In the Amarna period we find that both Aton and Pharaoh, his earthly image, are $s$ '. $y t d d$ ' $n h$, 'lifegiving Fate'. In a hymn Amon-Re, possibly in conscious opposition to the Amarna heresy, receives the epithet $p^{\prime} s^{\prime} \cdot y(t)$ $r n n . t$, 'fate and destiny'. ${ }^{3}$ In a late hymn to Isis from Assuan the goddess has $\check{s}^{\prime} . y t$ and $r n n . t$ under her command, which does not prevent her from

1 It is possible that a cosmic-astral interpretation of tyrannoi should be taken into consideration in v. 25 of the Cyme hymn: "I have broken down the governments of tyrants". To my mind the Greek hatred for the tyrants has been allowed to play an exaggerated role in the interpretation.

2 Morenz, op. cit. p. 24, n. 3. mentions some examples of this development of Egyptian fatalism which, according to him, is late.

${ }_{3}$ Translated by A. Erman, Die Literatur der Ägypter, Leipzig 1923, p. 382. Thus this occurs side by side with the more common expression with $n b$, e.g. concerning Ramses II at Abydos (Morenz, op. cit. p. 21): nb s'.yt śhpr rnn.t, "the lord of Fate, who creates destiny ('development')". - Moreover, there are a number of Egyptian parallels, in which one and the same concept appears both as abjective genetive and as an independent subject. Of special interest is the fact that Isis is both $n b . t$ $r n p . t$, "Mistress of the year" (i.e the one who brings and determines the new year, etc.) and $m p . t$, the year itself, when she is born on New Year's Day (cf. Brugsch, Thesaurus p. 102). She is also both $n b . t$ ' $n h$ and ' $n h$, i.e. the Mistress of Life and Life itself. 
being immediately afterwards identified with Rnn.t, i.e. Thermouthis. In this respect the Isis hymns from Medinet $\mathrm{Madi}^{1}$ are very instructive; here Hermouthis ( = Thermouthis) and Agathe Tyche and Isis are entirely on the same level (I, I-2; II, I-2, etc.), and we are entitled to recognize here the old combination Isis-š'.yt-rnn.t. Consequently, we need not have recourse to the Hellenistic cult of (Agathē) Tychē in order to understand this combination, even if this cult may have furthered and spread the idea. When Antoninus Pius' Egyptian titles include the name $\breve{S}$ '.w $n$ B'k.t, 'the Fate of Egypt', this might express a domestic tradition, even if the idea of the Agathos Daimon may have contributed to it. Late speculation about $\breve{S}^{\prime} . w$ as a primeval god, ${ }^{3}$ e.g. the following phrase in the large magical papyrus from Paris You pvougl vivinp (=p' $\breve{S}$ 'w p' ntr $n$ ntr.w), "Fate, the god of the gods", which at first sight might seem to contradict Egyptian views, can only be explained against that aspect of Egyptian development that has been dealt with here, according to which Fate and the god of Fate are not kept strictly apart.

Also corresponding to this are the combinations Isis Tyche (even written

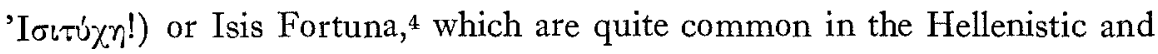
Roman world. It is Isis Fortuna that Lucius in Apuleius becomes acquainted with and who in a real sense becomes his Destiny, his Fortune.

"I overcome Fate. Fate harkens to me." This was the gospel of Isis. But how did the individual react to this? This paper will conclude with a sketch of some of the different lines along which Hellenistic man sought deliverance from Fate through Isis.

I. It is not surprising that magic was frequently resorted to. From of old Isis wore the epithet $w r . t h k^{\prime} . w$, 'great in magic spells', and consequently she plays a very significant role in the magical papyri.

2. Magic might be characterized as a special kind of gnosis. Astrology and alchemy border on this, and the statement: "One nature delights in another,

1 Most easily accessible in SEG VIII, $548-55 \mathrm{I}$.

2 Morenz, op. cit. p. 26.

3 Ib. pp. $26 \mathrm{f}$.

4 Several instances of this are given by G. Vandebeek, "De interpretatione graeca van het Isisfiguur", Studia Hellenistica 4, Louvain I946, pp. 54 ff. 
one nature overcomes another, one nature rules another"' has an important bearing on the latter. This sentence which is said to have the same provenience as our Cyme hymn, points to certain possible lines of connection be-

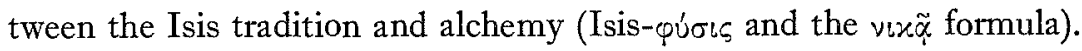

As for gnosis in the more traditional sense, we may refer to Hermetic literature, e.g. Corp. Herm. XII, 9: "Nous rules everything, both Fate (heimarmene) and law", where nous stands for the cosmic principle and the individual's share of it. Zosimus ${ }^{2}$ tells us that both Hermes and Zoroaster have maintained that "the race of the philosophers was superior to Fate (heimarmenēe)". Since Isis in the Cyme hymn declares that she was educated by Hermes himself, and since she and Osiris in the Kore Kosmou ${ }^{3}$ are entrusted with special revelations, it is natural that a certain amount of gnosis was easily connected with Isis' name, which Plutarch already wanted to relate etymologically to síin

3. Others placed the stress on conduct. An instance is provided by the following quotation from Lactantius (Div. inst. 2, I5,6): "For neither an evil demon, nor Fate (heimarmenē) has any power over a pious man. For God delivers the pious from all evil." The many ethical precepts of the Cyme hymn, mostly anchored in the myth of the goddess, called the initiates to

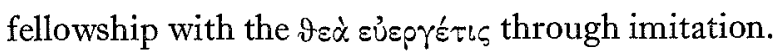

4. The most important way, which also included many of the elements already mentioned, was offered by the mystery cults. Initiation created a fellowship between the god and the initiate in life and death. The well known word in Firmicus Maternus (De errore prof. rel. 22, I) bears eloquent witness to this: "Be confident, O you initiates. Since the god has been saved, there is salvation also for us from our toil". In the Cyme hymn Isis declares: "I

1 For a discussion of this important doctrine the reader is referred to A.-J. Festugière, La révélation d'Hermès Trismégiste I, Paris I944, pp. 23I ff. Notice also that the three parts, which do not occur in a fixed order, often also appear independently. See also Bidez-Cumont, Les Mages Hellénisés II, Paris I938, pp. $3^{1} 3^{-} 3^{15}, 3^{18-320}$, where the tradition is ascribed to Ptah's temple at Memphis, p. 3I4, n. 2. For the age of the tradition, see vol. I p. 204 n. I.

2 Quoted by R. Reitzenstein, Poimandres, Leipzig 1904, p. 103.

${ }_{3}$ For Kore Kosmou the reader is referred to the introduction in the Budé edition (Hermès Trismégiste III, Paris 1954, pp. CxxvIII ff.) and to the monograph of A.-J. Festugière, "L'arétalogie isiaque de la Koré kosmou", Mélanges Picard, Paris I949, pp. $376 \mathrm{ff}$.

4-654218 Ringgren 
showed initiations unto men" (v. 22). Thus she points precisely to the myste-

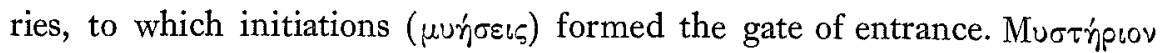
often became synonymous with sacramentum. A sacrament could overcome Fate as is shown by Exc. ex Theodoto 78,1: "Thus until baptism, they say, fate is true, but after this the astrologers do not speak the truth." The idea of regeneration or a new birth under the favourable horoscope of the saviour god, which seems to have been concretely depicted in he sanctuaries, is basic for most mystery cults, and the initiate consequently celebrated the day of his initiation as his real birthday. The garment that he put on was a symbol of the new life he entered through his initiation. There is evidence that the garment of the Isis initiate was to accompany him to the grave. It is obvious that we have here the same kind of symbolism that was the basis of the Egyptian mummification through which the deceased was identified with Osiris. The initiate shared the destiny of his god. And from the very first mummification referred to by the myth and represented in the rite, it was Isis who held this destiny in her hand. ${ }^{1}$

So we depart from Isis, who remains an Egyptian goddess ${ }^{2}$ also in the world of Hellenistic syncretism and is, as such, Mistress of Fate, even Fate itself, even though the disturbed, dualistic atmosphere of the time came especially to emphasize the victory over misfortune that her dominion of Fate seemed above all to imply.

\section{Abbreviations}

$A B A W$ Abhandlungen der Bayerischen Akademie der Wissenschaften zu München. $A P A W$ Abhandlungen der Preussischen Akademie der Wissenschaften zu Berlin. $A S A W$ Abhandlungen der Sächsichen Akademie der Wissenschaften zu Leipzig. CIL Corpus Inscriptionum Latinarum

HThR Harvard Theological Review.

IG Inscriptiones Graecae.

1 Cf. the following statement in the Kore Kosmou aretalogy: "They (i.e. Isis and Osiris) taught how to shroud those who have ceased to live" (Hermès Trismégiste IV, 2I, I9 f.).

2 "Im Kern blieb Isis Ägypterin" is the conclusion of S. Morenz' lecture on "Ägyptische Nationalreligion und sogenannte Isismission", ZDMG NF 36 (= I I I), I96r, pp. $432 \mathrm{ff}$. 
IPE Inscriptiones orae septentrionalis Ponti Euxini.

L.-Sc. Liddell-Scott, A Greek-English Lexicon.

$M D A I K$ Mitteilungen des Deutschen Archäologischen Instituts in Kairo.

PGM Papyri Graecae Magicae.

P.Oxy. Oxyrhynchus Papyri ed. B. P. Grenfell \& A. S. Hunt.

$R A R G$ Bonnet, Reallexikon der ägyptischen Religionsgeschichte, Berlin 1952.

$R E G \quad$ Revue des Études Grecques.

RHLR Revue d'Histoire et de Littérature Religieuses.

SEG Supplementum Epigraphicum Graecum.

UPZ Wilcken, Urkunden der Ptolemäerzeit I (Berlin 1922).

Urk. Urkunden des ägyptischen Altertums begr. von G. Steindorff.

$W B \quad$ Erman-Grapow, Wörterbuch der ägyptischen Sprache ${ }^{2}$, Berlin 1957.

ZDMG Zeitschrift der Deutschen Morgenländischen Gesellschaft. 